\title{
Nitrogen saturation and net ecosystem production
}

\author{
Arising from: F. Magnani et al. Nature 447, 848-850 (2007)
}

Magnani et al. ${ }^{1}$ found that net carbon (C) sequestration of temperate and boreal forests is clearly driven by nitrogen (N) deposition. From the positive relationship between average net ecosystem production (NEP) and wet N deposition, the authors further conclude that "no signs of N saturation were apparent" in the studied forests and that this is "casting doubts on the risk of widespread ecosystem nitrogen saturation". Nitrogen additions can clearly alter net ecosystem production, but net ecosystem production cannot be used as an indicator of $\mathrm{N}$ saturation.

Nitrogen saturation implies a change in $\mathrm{N}$ cycling from a closed internal cycle to an open cycle ${ }^{2}$ where excess $\mathrm{N}$ is leached and/or emitted from the forest ecosystem. These changes in forest ecosystem functioning have been extensively documented ${ }^{3,4}$. Examples from literature lead us to suggest that some of the forest ecosystems discussed in the concerned article might be $\mathrm{N}$ saturated, irrespective of the increased net ecosystem production. Evidence for $\mathrm{N}$ saturation has been observed in forest ecosystems subject to $\mathrm{N}$ deposition levels similar to the relatively low deposition range reported in the concerned $\operatorname{article}^{1}$ (that is, less than $10 \mathrm{~kg} \mathrm{Nha}^{-1} \mathrm{yr}^{-1}$ wet deposition), including considerable nitrate loss (up to $10 \mathrm{~kg} \mathrm{~N} \mathrm{ha}^{-1} \mathrm{yr}^{-1}$ ) through runoff or seepage water ${ }^{5-7}$ and elevated emissions of $\mathrm{NO}$ and $\mathrm{N}_{2} \mathrm{O}^{8}$. Because Magnani et al. ${ }^{1}$ did not measure any of these pathways of $\mathrm{N}$ loss, they cannot rule out $\mathrm{N}$ saturation in the studied forest ecosystems.

The demonstrated relationship between $\mathrm{N}$ deposition and $\mathrm{C}$ sequestration is an important finding, consistent with other literature $^{9}$. In our opinion, however, Magnani et al. ${ }^{1}$ demonstrate an incorrect view on the phenomenon of $\mathrm{N}$ saturation and, in doing so, greatly ignore the effect of $\mathrm{N}$ deposition and saturation on soil acidification, groundwater and surface water quality, biodiversity, and ecosystem services other than $\mathrm{C}$ sequestration. Because the data presented by Magnani et al. ${ }^{1}$ do not allow an evaluation of the $\mathrm{N}$ saturation status of the studied forests, the expressed "doubts on the risk of widespread ecosystem nitrogen saturation" are not substantiated. At the moment, $\mathrm{N}$ saturation of forest ecosystems is probably not yet a widespread problem on a global scale, but it is surely a widespread problem in densely populated and more industrialized regions ${ }^{4,7}$. From the Europe-covering IFEF (Indicators of Forest Ecosystem Functioning) and Level-II (UN-ECE/EC intensive monitoring plots) databases $^{10,11}$, it can be deduced that more than $25 \%$ of the European forests included in these databases are $\mathrm{N}$ saturated (considering the nitrate seepage flux as indicator and $5 \mathrm{~kg}(357 \mathrm{~mol}) \mathrm{N} \mathrm{ha}^{-1} \mathrm{yr}^{-1}$ as a threshold value of $\mathrm{N}$ saturation). Furthermore, from a large number of sites in the northeastern United States ${ }^{4}, \mathrm{~N}$ saturation was indicated as a frequently occurring phenomenon. As substantial increases in global $\mathrm{N}$ emissions are predicted for the coming $50 \mathrm{yr}^{12}$, the potential risk of widespread $\mathrm{N}$ saturation of forest ecosystems in the long term cannot be denied.

An De Schrijver ${ }^{1}$ Kris Verheyen ${ }^{1}$, Jan Mertens ${ }^{1}$, Jeroen Staelens ${ }^{1}$, Karen Wuyts ${ }^{1} \&$ Bart Muys ${ }^{2}$

${ }^{1}$ Laboratory of Forestry, Ghent University, Geraardsbergse Steenweg

267, 9090 Gontrode, Belgium.

e-mail: An.Deschrijver@Ugent.be

${ }^{2}$ Division Forest, Nature and Landscape, Katholieke Universiteit Leuven, Celestijnenlaan 200E, 3001 Leuven, Belgium.

Received 20 July; accepted 30 October 2007.

1. Magnani, F. et al. The human footprint in the carbon cycle of temperate and boreal forests. Nature 447, 848-850 (2007).

2. Matson, P., Lohse, K. A. \& Hall, S. J. The globalization of nitrogen deposition: Consequences for terrestrial ecosystems. Ambio 31, 113-119 (2002).

3. Aber, J. D. et al. Nitrogen saturation in temperate forest ecosystems-Hypotheses revisited. Bioscience 48, 921-934 (1998).

4. Aber, J. D. et al. Is nitrogen deposition altering the nitrogen status of northeastern forests? Bioscience 53, 375-389 (2003).

5. Dise, N. B., Matzner, E. \& Gundersen, P. Synthesis of nitrogen pools and fluxes from European forest ecosystems. Wat. Air Soil Pollut. 105, 143-154 (1998).

6. Macdonald, J. A. et al. Nitrogen input together with ecosystem nitrogen enrichment predict nitrate leaching from European forests. Glob. Change Biol. 8, 1028-1033 (2002).

7. Gundersen, P. K., Schmidt, I. K. \& Raulund-Rasmussen, K. Leaching of nitrate from temperate forests-effects of air pollution and forest management. Environ. Rev. 14, $1-57$ (2006).

8. Pilegaard, K. et al. Factors controlling regional differences in forest soil emission of nitrogen oxides ( $\mathrm{NO}$ and $\mathrm{N}_{2} \mathrm{O}$ ). Biogeosciences 3, 651-661 (2006).

9. Karjalainen, T. et al. Causes and Consequences of Forest Growth Trends in EuropeResults of the RECOGNITION Project. European Forest Institute Research Report (Brill, Leiden, in the press).

10. Lorenz, M. et al. Nitrogen retention and release in European forests: Deriving indicators from large databases. In Forest Condition in Europe: 2005 Technical Report (Federal Research Centre for Forestry and Forest Products (BFH), UNECE Geneva, 2005).

11. Van der Salm, C., de Vries, W., Reinds, G. J. \& Dise, N. B. N leaching across European forests: Derivation and validation of empirical relationships using data from intensive monitoring plots. For. Ecol. Manage. 238, 81-91 (2007).

12. Galloway, J. N. et al. Nitrogen cycles: past, present, and future. Biogeochemistry 70, 153-226 (2004).

doi:10.1038/nature06578

\section{Ecologically implausible carbon response?}

\author{
Arising from: F. Magnani et al. Nature 447, 848-850 (2007)
}

Magnani et al. ${ }^{1}$ present a very strong correlation between mean lifetime net ecosystem production (NEP, defined as the net rate of carbon (C) accumulation in ecosystems ${ }^{2}$ ) and wet nitrogen $(\mathrm{N})$ deposition. For their data in the range $4.9-9.8 \mathrm{~kg} \mathrm{~N} \mathrm{ha}^{-1} \mathrm{yr}^{-1}$, on which the correlation largely depends, the response is approximately $725 \mathrm{~kg} \mathrm{C}$ per $\mathrm{kg} \mathrm{N}$ in wet deposition. According to the authors, the maximum $\mathrm{N}$ wet deposition level of $9.8 \mathrm{~kg} \mathrm{~N} \mathrm{ha}^{-1} \mathrm{yr}^{-1}$ is equivalent to a total deposition of $15 \mathrm{~kg} \mathrm{Nha}^{-1} \mathrm{yr}^{-1}$, implying a net sequestration near $470 \mathrm{~kg} \mathrm{C}$ per $\mathrm{kg} \mathrm{N}$ of total deposition. We question the ecological plausibility of the relationship and show, from a multi-factor analysis of European forest measurements, how interactions with site productivity and environment imply a much smaller $\mathrm{NEP}$ response to $\mathrm{N}$ deposition.

The $\mathrm{C}$ response to $\mathrm{N}$ deposition is restricted by the C:N stoichiometry of the forest ecosystem compartments. The implied NEP response of $470 \mathrm{~kg} \mathrm{C}$ per $\mathrm{kg} \mathrm{N}$ would require that the fate of the deposited nitrogen was exclusively in stem wood, which is the only carbon sink with a C:N ratio of this magnitude. This is unreasonable because $\mathrm{N}$-limited forest stands, as suggested ${ }^{1}$, invest primarily in roots $^{3}$, with C:N ratios near 50-100. The impossibility of near-total 
Table 1 | Multivariate regression results at stand level and individual tree level

\begin{tabular}{|c|c|c|c|c|c|c|}
\hline \multicolumn{7}{|c|}{ a Results at stand level for $\mathrm{N}$ sensitive plots with parameter estimates } \\
\hline Tree species & Site productivity* & Age† & SDI: & $\mathrm{N}$ deposition§ & Drought || & Temperature change \\
\hline \multicolumn{7}{|l|}{ All plots } \\
\hline Norway spruce & 0.054 & -0.005 & - & $0.020 \#$ & - & 0.524 \\
\hline Scots pine & - & -0.017 & - & 0.010 & -0.0032 & - \\
\hline \multicolumn{7}{|l|}{ Sensitive plots } \\
\hline Norway spruce & 0.039 & -0.004 & - & 0.022 & - & 0.32 \\
\hline Scots pine & - & -0.017 & 0.001 & 0.013 & -0.002 & - \\
\hline
\end{tabular}

b Results at individual tree level with parameter estimates for the main influencing factors included

\begin{tabular}{|c|c|c|c|c|c|c|}
\hline Tree species & BAL场 & SDI: & $\mathrm{C}: \mathrm{N}_{\mathrm{soil}} * *$ & $\mathrm{~N}$ deposition§ & Temperature $\dagger \dagger$ & Temperature change \\
\hline Norway spruce & -0.39 & -0.00056 & -0.023 & 0.013 & - & - \\
\hline Scots pine & -0.29 & -0.00066 & - & 0.015 & 0.053 & - \\
\hline Common beech & -0.16 & - & - & 0.012 & - & 0.064 \\
\hline Oak & -0.38 & -0.00062 & - & 0.013 & 0.080 & - \\
\hline
\end{tabular}

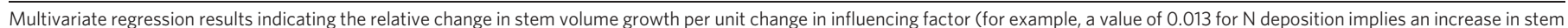

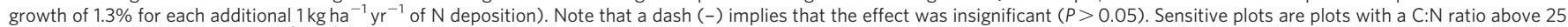

$*$ Site productivity is a variable $\left(\mathrm{m}^{3} \mathrm{ha}^{-1} \mathrm{yr}^{-1}\right)$ derived from selected European site index curves, with input variables being age and top height.

$\uparrow$ Stand age (yr).

$\$$ SDI, stand density index (number of trees per ha).

$\S \mathrm{N}$ deposition is total $\mathrm{N}$ deposition (unit change: $\mathrm{kg} \mathrm{ha}^{-1} \mathrm{yr}^{-1}$ )

| Drought is a variable describing drought given as a relative value (unit change: \%) to the normal (30-yr mean) drought stress at each site.

-The temperature difference during the growing period compared with the 30 -yr average temperature (unit change: ${ }^{\circ} \mathrm{C}$ ).

\#Results from a linear regression; in the multivariate analysis the coefficient was just not significant at $P<0.05$.

is BAL is basal area of larger trees, which affects tree competition $\left(\mathrm{m}^{2} \mathrm{ha}^{-1}\right)$.

** C: $\mathrm{N}_{\text {soil }}$ is the $\mathrm{C}: \mathrm{N}$ ratio of the mineral topsoil $(0-30 \mathrm{~cm})$.

†T Temperature is average yearly temperature during the investigation period $1993-2000\left({ }^{\circ} \mathrm{C}\right)$.

storage of deposited $\mathrm{N}$ in stem wood follows also from the expected $\mathrm{N}$ leaching rates, varying between $10-50 \%$ of the $\mathrm{N}$ input in a range of 10-25 $\mathrm{kg} \mathrm{N} \mathrm{ha}^{-1} \mathrm{yr}^{-1}$ (refs 4, 5), which is the likely range for total $\mathrm{N}$ deposition at the plots of Magnani et al. ${ }^{1}$ where the high C:N response was found (that is, their European sites where wet $\mathrm{N}$ deposition was estimated at $4.9-9.8 \mathrm{~kg} \mathrm{Nha}^{-1} \mathrm{yr}^{-1}$ ). This total $\mathrm{N}$ deposition range follows from an application of the EMEP (European Monitoring and Evaluation Programme of the Long-range Transmission of Air Pollutants) model, used in the NITROEUROPE project, for the year 2000 to the sites of Magnani et al. ${ }^{1}$. Using this model, the estimates of which are in close agreement with measured atmospheric $\mathrm{N}$ deposition at forest sites ${ }^{6}$, we found that total $\mathrm{N}$ deposition at the sites of Magnani et al. ${ }^{1}$ is 2-7 times greater than wet deposition. This analysis implies a relationship of approximately $175 \mathrm{kgC}$ per $\mathrm{kg} \mathrm{N}$ in the mentioned total $\mathrm{N}$ deposition range.

However, even this lower response is unlikely. ${ }^{15} \mathrm{~N}$-labelled tracer experiments in temperate forests indicate that $\mathrm{N}$ retention hardly occurs in stem wood but mainly in the soil ${ }^{7}$. Considering the fate of $\mathrm{N}$ and the ranges in $\mathrm{C}: \mathrm{N}$ ratios in forest ecosystem compartments, this implies a carbon response near $50 \mathrm{~kg} C$ per $\mathrm{kg} \mathrm{N}$ in forest ecosystems $^{7,8}$. Even though the above-ground $\mathrm{C}$ sequestration may be underestimated by Nadelhoffer et al. ${ }^{7}$, owing to neglecting the effect of direct foliar uptake $e^{9,10}$, this effect is likely to be small, as aboveground foliar $\mathrm{N}$ uptake is generally less than $5 \mathrm{~kg} \mathrm{Nha}^{-1} \mathrm{yr}^{-1}$ (ref. 11), whereas below-ground uptake is generally more than $50 \mathrm{~kg} \mathrm{Nha}^{-1} \mathrm{yr}^{-1}$. Furthermore, similar results are found in longterm (15-30 yr) nitrogen-fertilizer trials at rates of nitrogen addition below $50 \mathrm{~kg} \mathrm{Nha}^{-1} \mathrm{yr}^{-1}$ (refs 12,13) and in process-based model simulations ${ }^{14}$. The reason for the extremely high influence of $\mathrm{N}$ deposition on NEP suggested by Magnani et al. ${ }^{1}$ is probably due to the contribution of other factors - which co-vary with wet $\mathrm{N}$ deposition-to the derived relationship. The authors filtered out the effects of age and investigated the separate effect of temperature but they aggregated all tree species and site characteristics, such as site fertility and stand density, into one relationship.

We carried out a multi-factor analysis of measured forest growth data at nearly 400 intensively monitored forest plots in Europe, including Norway spruce, Scots pine, common beech and oak. The influence of nitrogen and acid deposition was considered by using values during the growth period (1993-2000), whereas the impacts of temperature, precipitation and drought were addressed by taking the deviation of these climatic parameters in the growth period (19932000) from the 30-yr mean. We simultaneously accounted for site factors influencing measured tree growth, including site productivity, stand age and stand density. We also applied a multi-factor analysis with measured basal-area increment of each individual tree as responding factor. The influencing factors used in this study and the results of the multivariate analyses at stand and individual tree level are shown in Table 1. The approach at tree level indicated a 1.2$1.5 \%$ increase in basal-area increment, depending on tree species, in response to $1 \mathrm{~kg}$ of $\mathrm{Nha}^{-1} \mathrm{yr}^{-1}$. The approach at stand level indicated only a significant response of Norway spruce and Scots pine to $\mathrm{N}$ with roughly a $1-2 \%$ increase in volume growth in response to $1 \mathrm{~kg}$ of $\mathrm{N} \mathrm{ha}^{-1} \mathrm{yr}^{-1}$, depending on the C:N ratio of the plots. We recalculated these responses in terms of $\mathrm{C}$ sequestration by multiplying the mean measured volume growth at each stand with the estimated growth increase and the mean wood density of each tree species, assuming a $\mathrm{C}$ content of $50 \%$. The results of our analyses at both tree and stand level indicate a response of trees between approximately $20-40 \mathrm{~kg} C$ per $\mathrm{kg} \mathrm{N}$. Additionally, results of long-term nitrogen addition experiments indicate soil responses of $10-30 \mathrm{~kg} \mathrm{C}$ per $\mathrm{kg} \mathrm{N}^{12,13,15}$. Thus, the total NEP response would be about $30-70 \mathrm{kgC}$ per $\mathrm{kg} \mathrm{N}$, which is much smaller than that estimated by Magnani et al. ${ }^{1}$.

\section{METHODS}

The multivariate regression at stand level was carried out by a backward stepwise method, where the model was reduced step-by-step by removing nonsignificant effects. The results of the hypothesis testing of the effects are based on partial $F$-tests.

The multivariate regression analysis at tree level was carried out by using tree size and tree competition variables on tree level and site factors and environmental factors on plot level, including plot as a random effect and applying the restricted maximum likelihood (REML) method for parameter estimation. Parameters in the model, which exhibited significant $(P<0.05)$ coefficients and behaved according to their known impacts, are included in Table $1 \mathrm{~b}$. We accounted for correlations, such as those between climatic parameters and $\mathrm{N}$ deposition (for example, we found a quadratic relation between $\mathrm{N}$ deposition and temperature; $R^{2}=0.62$ ).

Wim de Vries', Svein Solberg ${ }^{2}$, Matthias Dobbertin ${ }^{3}$, Hubert Sterba ${ }^{4}$, Daniel Laubhahn ${ }^{4}$, Gert Jan Reinds ${ }^{1}$, Gert-Jan Nabuurs ${ }^{1}$, Per Gundersen ${ }^{5}$ \& Mark A. Sutton ${ }^{6}$

${ }^{1}$ Alterra, Wageningen University and Research Centre, PO Box 47, 6700 AA Wageningen, The Netherlands.

e-mail:wim.devries@wur.nl 
${ }^{2}$ Norwegian Forest and Landscape Institute, PO Box 115, N-1431 Ås, Norway.

${ }^{3}$ Swiss Federal Institute for Forest, Snow and Landscape Research WSL, Zürcherstrasse 111, CH-8903 Birmensdorf, Switzerland.

${ }^{4}$ University of Natural Resources and Applied Life Sciences, Peter Jordan-Straße 82, A-1190 Vienna, Austria.

${ }^{5}$ Danish Centre for Forest, Landscape and Planning, University of Copenhagen, Hoersholm, Denmark.

${ }^{6}$ Centre for Ecology and Hydrology, Edinburgh Research Station, Bush Estate, Penicuik, Midlothian, EH26 OQB, UK.

Received 23 July; accepted 16 November 2007.

1. Magnani, F. et al. The human footprint in the carbon cycle of temperate and boreal forests. Nature 447, 848-850 (2007)

2. Woodwell, G. M. \& Whittaker, R. H. Primary production in terrestrial ecosystems. Am. Zool. 8, 19-30 (1968).

3. Brouwer, R. Functional equilibrium: sense or nonsense. Neth. J. Agric. Sci. 31, 335-348 (1983).

4. Gundersen, P., Schmidt, I. K. \& Raulund-Rasmussen, K. Leaching of nitrate from temperate forests - effects of air pollution and forest management. Environ. Rev. 14 1-57 (2006)

5. De Vries, W., van der Salm, C., Reinds, G. J. \& Erisman, J. W. Element fluxes through European forest ecosystems and their relationships with stand and site characteristics. Environ. Pollut. 148, 501-513 (2007).
6. Simpson, D., Fagerli, H., Hellsten, S., Knulst, J. C. \& Westling, O. Deposition and emissions of reactive nitrogen over European forests: A modelling study. Biogeosciences 3, 337-355 (2006).

7. Nadelhoffer, K. J. et al. Nitrogen deposition makes a minor contribution to carbon sequestration in temperate forests. Nature 398, 145-148 (1999).

8. De Vries, W., Reinds, G. J., Gundersen, P. \& Sterba, H. The impact of nitrogen deposition on carbon sequestration in European forests and forest soils. Glob. Change Biol. 12, 1151-1173 (2006).

9. Jenkinson, D. S., Goulding, K. \& Powlson, D. S. Nitrogen deposition and carbon sequestration. Nature 400, 629 (1999).

10. Sievering, H. Nitrogen deposition and carbon sequestration. Nature 400, 629-630 (1999).

11. Sievering, H., Fernandez, I., Lee, J., Hom, J. \& Rustad, L. Forest canopy uptake of atmospheric nitrogen deposition at eastern US conifer sites: Carbon storage implications? Glob. Biogeochem. Cycles 14, 1153-1160 (2000).

12. Hyvönen, R. et al. Impact of long-term nitrogen addition on carbon stocks in trees and soils in northern Europe. Biogeochemistry doi:10.1007/s10533-007-9121-3 (2007).

13. Högberg, P., Fan, H., Quist, M., Binkley, D. \& Tamm, C. O. Tree growth and soil acidification in response to 30 years of experimental nitrogen loading on boreal forest. Glob. Change Biol. 12, 489-499 (2006).

14. Levy, P. E., Wendler, R., Van Oijen, M., Cannell, M. G. R. \& Millard, P. The effect of nitrogen enrichment on the carbon sink in coniferous forests: uncertainty and sensitivity analyses of three ecosystem models. Water Air Soil Pollut. Focus 4, 67-74 (2004).

15. Evans, C. D. et al. Modelling nitrogen saturation and carbon accumulation in heathland soils under elevated nitrogen deposition. Environ. Pollut. 143, 468-478 (2006).

doi: $10.1038 /$ nature06579

\section{Magnani et al. reply}

Replying to: A. De Schrijver et al. Nature 451, doi:10.1038/nature06578; W. de Vries et al. Nature 451, doi:10.1038/nature06579 (2008)

Nitrogen $(\mathrm{N})$ deposition alters ecosystem function in several ways, with important effects on $\mathrm{N}$ leaching and water quality, as well as on interspecific competition and biodiversity. These changes have been attributed to ecosystem $\mathrm{N}$ saturation, defined as the alleviation of $\mathrm{N}$ limitations on rates of biological function ${ }^{1}$. After an initial fertilization effect, $\mathrm{N}$ saturation has also been suggested to reduce plant function and growth ${ }^{2}$, eventually leading to forest dieback. Although our observation of a substantial positive effect of $\mathrm{N}$ deposition on forest carbon $(\mathrm{C})$ sequestration ${ }^{3}$ does not imply the absence of nitrate losses or other negative effects, as rightly stressed by De Schrijver et al. ${ }^{4}$, the sustained response observed demonstrates that the fear of a generalized forest decline in response to $\mathrm{N}$ fertilization could be overstated, at least within the rather broad $\mathrm{N}$ deposition range explored in our analysis. The nature of the observed response of forest $\mathrm{C}$ sequestration to $\mathrm{N}$ deposition, however, has been questioned outright by de Vries et al. ${ }^{5}$, who suggested that it could be an artefact resulting from the covariation between $\mathrm{N}$ deposition and other environmental variables. The arguments proposed against an overwhelming $\mathrm{N}$ effect, however, do not seem to stand up to close scrutiny.

We agree that ecosystem gross primary production (GPP) and plant growth are, to a large extent, controlled by local climate, drought and fertility (that is, $\mathrm{N}$ mineralization associated with soil organic matter decomposition), although fertility could be itself influenced by current and past $\mathrm{N}$ deposition ${ }^{6}$. However, the same environmental factors would modulate in parallel ecosystem respiration, and as a result do not seem to affect net ecosystem production (NEP), which is the difference between GPP and ecosystem respiration and is the subject of our analysis ${ }^{3}$. Both components of NEP seem to be also affected by $\mathrm{N}$ deposition, but in opposite directions: apart from the positive effects on plant growth considered by de Vries et al. ${ }^{5}$, respiration is known to be significantly reduced by $\mathrm{N}$ fertilization, as demonstrated by manipulation experiments ${ }^{7,8}$ as well as regional transect studies 9 . The combined effect at the ecosystem level is largely missed when focusing on tree growth alone.

The question remains of the magnitude of the observed response to $\mathrm{N}$ deposition. Assuming a linear relationship between NEP and N deposition, a slope of $445 \pm 38 \mathrm{~kg}$ C per $\mathrm{kg} \mathrm{N}$ of wet $\mathrm{N}$ deposition can be inferred from our entire data set $(n=20$, rather than the subsample of 8 data points in the analysis by de Vries et al. ${ }^{5}$ ). If we assume, rather conservatively, that wet deposition constitutes 40$50 \%$ of total $\mathrm{N}$ deposition ${ }^{10}$, this would imply a NEP sensitivity to total $\mathrm{N}$ deposition of approximately $175-225 \mathrm{~kg} \mathrm{C}$ per $\mathrm{kg} \mathrm{N}$, which is consistent with the stoichiometry of plant tissues and soil organic matter. Although it is true that fine roots account for a significant fraction of forest growth, it should be noted that one of the main effects of increased $\mathrm{N}$ availability is an increased allocation to woody tissues (with a high C:N ratio of up to 500:1) away from fine roots ${ }^{11}$. This mechanism could indeed represent an important component of the observed response to $\mathrm{N}$ deposition.

Far from implausible, a 200:1 sensitivity is nevertheless higher than suggested by long-term forest fertilization experiments ${ }^{12}$. Potential problems with $\mathrm{N}$ manipulation studies have already been discussed ${ }^{13}$. In particular, they overlook the role of canopy $\mathrm{N}$ uptake, which enables plants to absorb a relevant fraction of incoming $\mathrm{N}$ without any competition from soil microbes. Canopy $\mathrm{N}$ uptake amounts to up to $70 \%$ of $\mathrm{N}$ deposition, providing as much as one-third of tree $\mathrm{N}$ requirements ${ }^{9,14,15}$. The critical comparison of results from ecosystem manipulation and observational studies could be providing a rare, unforeseen insight into the key factors controlling $\mathrm{C}-\mathrm{N}$ relations in forest ecosystems.

Federico Magnani ${ }^{1}$, Maurizio Mencuccini ${ }^{2}$, Marco Borghetti ${ }^{3}$, Frank Berninger ${ }^{4}$, Sylvain Delzon ${ }^{5}$, Achim Grelle ${ }^{6}$, Pertti Hari ${ }^{7}$, Paul G. Jarvis ${ }^{2}$, Pasi Kolari ${ }^{7}$, Andrew S. Kowalski ${ }^{8}$, Harry Lankreijer ${ }^{9}$, Beverly E. Law ${ }^{10}$, Anders Lindroth ${ }^{9}$, Denis Loustau ${ }^{11}$, Giovanni Manca ${ }^{12}$, John B. Moncrieff ${ }^{2}$, Vanessa Tedeschi ${ }^{3}$, Riccardo Valentini ${ }^{13}$ \& John Grace ${ }^{2}$

${ }^{1}$ Department of Fruit Tree and Woody Plant Science, University of Bologna, Bologna I-40127, Italy.

e-mail: federico.magnani@unibo.it

${ }^{2}$ School of GeoSciences, University of Edinburgh, Edinburgh EH93JU, UK. ${ }^{3}$ Department of Crop Systems, Forestry and Environmental Sciences, University of Basilicata, Potenza I-85100, Italy. 
${ }^{4}$ Departement des Sciences Biologiques, University of Québec à Montréal, Montréal, Quebec H3C 3P8, Canada.

${ }^{5}$ UMR BIOGECO, INRA-Université Bordeaux 1, F-33400 Talence Cedex, France.

${ }^{6}$ Department of Ecology and Environmental Research, Swedish University of Agricultural Sciences, SE-75007 Uppsala, Sweden. ${ }^{7}$ Department of Forest Ecology, University of Helsinki, FIN-00014 Helsinki, Finland.

${ }^{8}$ Department of Applied Physics, University of Granada, E-18071 Granada, Spain.

${ }^{9}$ Department of Physical Geography and Ecosystems Analysis, Lund University, S-223 62 Lund, Sweden.

${ }^{10}$ College of Forestry, Oregon State University, Corvallis, Oregon 97331, USA.

${ }^{11}$ INRA, UR1263 EPHYSE, F-33883 Villenave d'Ornon, France.

${ }^{12}$ Institute for Environment and Sustainability-Climate Change Unit, Joint Research Center, European Commission, I-21020 Ispra, Italy.

${ }^{13}$ Department of Forest Resources and Environment, University of Tuscia, Viterbo I-01100, Italy.

1. Aber, J. D. et al. Nitrogen saturation in temperate forest ecosystems. Bioscience 48 , 921-934 (1998)

2. Aber, J. D. et al. Is nitrogen deposition altering the nitrogen status of northeastern forests? Bioscience 53, 375-389 (2003).

3. Magnani, F. et al. The human footprint in the carbon cycle of established temperate and boreal forests. Nature 447, 848-850 (2007).
4. De Schrijver, A. et al. Nitrogen saturation and net ecosystem production. Nature 451, doi:10.1038/nature06578 (2008).

5. de Vries, W. et al. Ecologically implausible carbon response? Nature 451, doi:10.1038/ nature06579 (2008).

6. Spiecker, H. Overview of recent growth trends in European forests. Wat. Air Soil Pollut. 116, 33-46 (1999).

7. Bowden, R. D., Davidson, E., Savage, K., Arabia, C. \& Steudler, P. Chronic nitrogen additions reduce total soil respiration and microbial respiration in temperate forest soils at the Harvard Forest. For. Ecol. Manage. 196, 43-56 (2004).

8. Olsson, P., Linder, S., Giesler, R. \& Högberg, P. Fertilization of boreal forest reduces both autotrophic and heterotrophic soil respiration. Glob. Change Biol. 11, 1745-1753 (2005).

9. Schulze, E.-D. (ed.) Carbon and Nitrogen Cycling in European Forest Ecosystems (Springer, Berlin, 2000).

10. Dentener, F. et al. Nitrogen and sulfur deposition on regional and global scales. A multimodel evaluation. Glob. Biogeochem. Cycles 20, GB4003 (2006).

11. Litton, C. M., Raich, J. W. \& Ryan, M. G. Carbon allocation in forest ecosystems. Glob. Change Biol. 13, 2089-2109 (2007).

12. Hyvönen, R. et al. Impact of long-term nitrogen addition on carbon stocks in trees and soils in northern Europe. Biogeochemistry doi:10-1007/s10533-007-9121-3 (2007).

13. Sievering, H. Nitrogen deposition and carbon sequestration. Nature 400,629-630 (1999).

14. Sievering, H., Tomaszewski, T. \& Torizzo, J. Canopy uptake of atmospheric N deposition at a conifer forest. Part I-Canopy N budget, photosynthetic efficiency and net ecosystem exchange. Tellus 59B, 483-492 (2007).

15. Gaige, E. et al. Changes in canopy processes following whole-forest canopy nitrogen fertilization of a mature spruce-hemlock forest. Ecosystems 10, 1133-1147 (2007).

doi: $10.1038 /$ nature 06580 